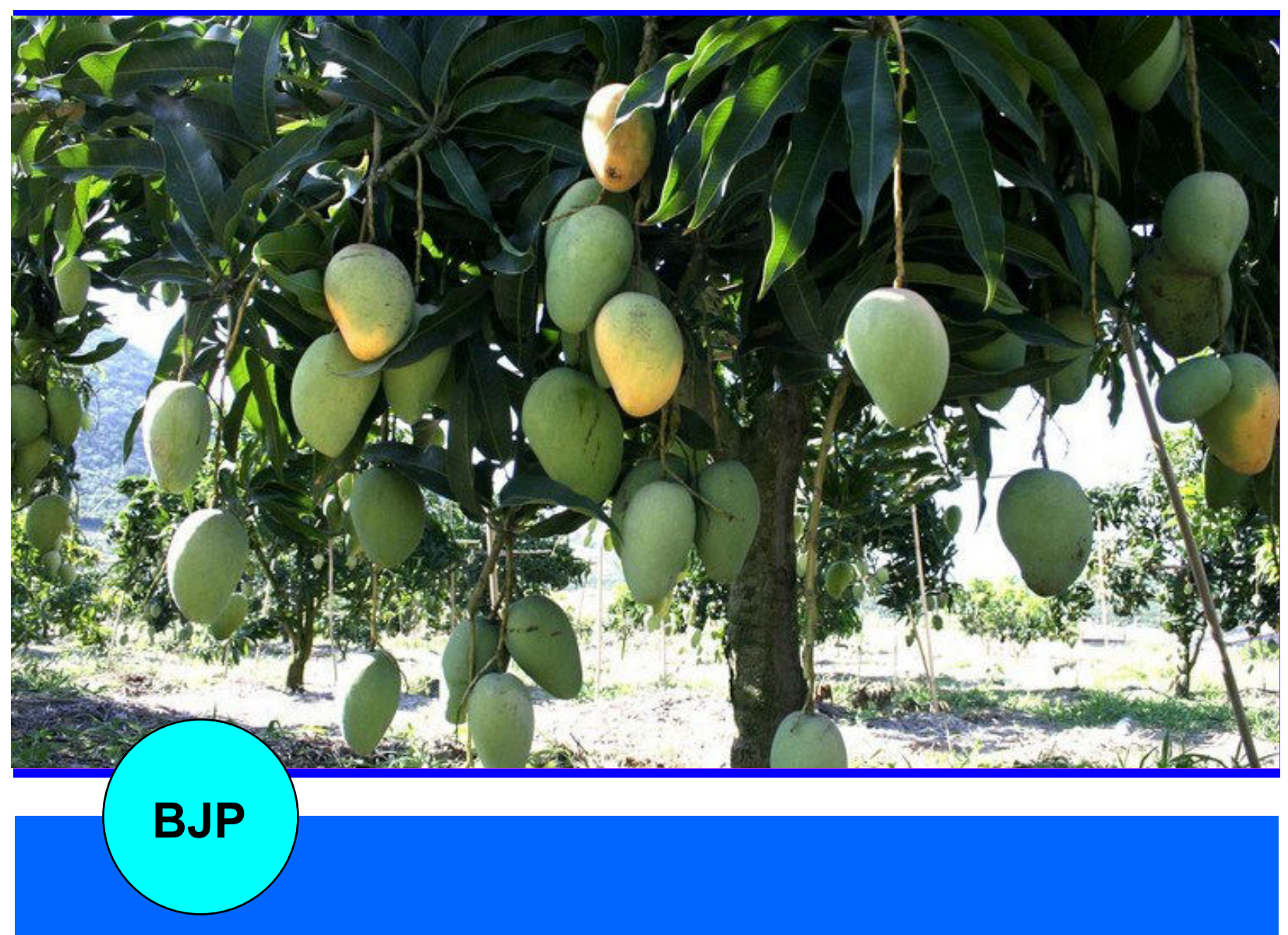

Bangladesh Journal of Pharmacology

Research Article

Studies on the antidiabetic effects of Mangifera indica stem-barks and leaves on nondiabetic, type 1 and 2 diabetic model rats 
Abstracted/indexed in Academic Search Complete, Agroforestry Abstracts, Asia Journals Online, Bangladesh Journals Online, Biological Abstracts, BIOSIS Previews, CAB Abstracts, Current Abstracts, Directory of Open Access Journals, EMBASE/Excerpta Medica, Google Scholar, HINARI (WHO), International Pharmaceutical Abstracts, Open J-gate, Science Citation Index Expanded and Social Sciences Citation Index

ISSN: $1991-0088$

\title{
Studies on the antidiabetic effects of Mangifera indica stem-barks and leaves on nondiabetic, type 1 and 2 diabetic model rats
}

\author{
Amrita Bhowmik', Liakot Ali Khan', Masfida Akhter² and Begum Rokeya² \\ ${ }^{1}$ Department of Biochemistry and Molecular Biology, Jahangirnagar University, Savar, Dhaka, Bangladesh; \\ ${ }^{2}$ Department of Pharmacology, BIRDEM, Dhaka 1000, Bangladesh.
}

\begin{tabular}{|c|c|}
\hline \multicolumn{2}{|l|}{ Article Info } \\
\hline Received: & 16 May 2009 \\
\hline Accepted: & 16 May 2009 \\
\hline Available Online: & 20 May 2009 \\
\hline \multicolumn{2}{|c|}{ DOI: $10.3329 /$ bjp.v4i2.2488 } \\
\hline \multicolumn{2}{|c|}{$\begin{array}{l}\text { Cite this article: } \\
\text { Bhowmik A, Khan LA, Akhter M, } \\
\text { Rokeya B. Studies on the antidiabetic } \\
\text { effects of Mangifera indica stem-barks } \\
\text { and leaves on nondiabetic, type } 1 \text { and } \\
\text { type } 2 \text { diabetic model rats. Bangla- } \\
\text { desh J Pharmacol. 2009; } 4: 110-14 \text {. }\end{array}$} \\
\hline
\end{tabular}

\begin{abstract}
Mangifera indica Linn, locally known as mango tree has been claimed to possess antidiabetic properties by many investigators. The present study was undertaken to screen the hypoglycemic and antihyperglycemic activity of both ethanol and water extracts of leaves and stem-barks of $M$. indica in nondiabetic and diabetic model rats in different prandial state. The results showed that all of the extracts had significant antihyperglycemic effect in type 2 diabetic model rats when fed simultaneously with glucose load $(\mathrm{p}<0.05-$ $0.01 ; p<0.005-0.001)$. Moreover, the ethanol extract of stem-barks showed significant antihyperglycemic effect when the extract was fed $30 \mathrm{~min}$ prior to the glucose load $(p<0.01)$. Investigations were carried out to evaluate the effect of $M$. indica on glucose absorption using a rat intestinal preparation in situ. The ethanol extracts of stem-barks reduced glucose absorption gradually
\end{abstract}

\section{Introduction}

Diabetes mellitus is ranked seventh among the leading causes of death and third when it's fatal complications are taken into account (Trivedi et al., 2004). Traditional preparations of plant sources are widely used almost everywhere in the world to treat this disease. Therefore, plant materials are considered to be the alternative sources for finding out new leads for hypo/antihyperglycemic agents.

Following a standardized procedure (Ali et al., 1993) antidiabetic plant materials are being screened in BIRDEM for their hypoglycemic properties. Experiment on normal, type 1 and type 2 diabetic model rats at different prandial states have been combined in this experimental approach, which screens materials for hypo-/antihyperglycemic activity as well as provide an approximate idea on the possible target tissue(s) involved. Mangifera indica has been reported to have hypoglycemic effect in both laboratory animals (Ojewole et al., 2005; Muruganandan et al., 2005; Perpetuo et al., 2003; Aderibigbe et al., 2001; Sharma et al., 1997) and human diabetic subjects (Mahabir et al., 1997). The purpose of this work was to evaluate the hypo- and antihyperglycemic effects of $M$. indica in normal and both type of diabetic model rats and to find out their possible mode(s) of antidiabetic action.

\section{Material and Methods}

Plant materials and preparation of test samples: $M$. indica Linn. leaves and stem-barks were collected from the garden of the Pritilata Hall, Jahangirnagar University, Savar, Dhaka in the month of February 2007. Newly grown, fresh, green leaves (931 g) and skin of the stembarks (893 g) of $M$. indica were pasted by homogenizing with mortar and were suspended with water for preparing the water extract and finally $800 \mathrm{~mL}$ of stem -barks and leaves water extract were collected. A portion of stem-barks and leaves paste were dissolved in absolute ethanol (96\% ethanol) and filtered. Suspensions were dried using a rotary vacuum evaporator (BUCHI Rota vapor R-114). These semisolid extracts were again dried with water bath at $80^{\circ} \mathrm{C}$. The amount 
of total ethanol extract of stem-barks and leaves were found to be $30.1 \mathrm{~g}$ and $35.3 \mathrm{~g}$. These dried extracts were kept in the Frazer and utilized for biological screening at BIRDEM.

Animals: The experiments were carried out on LongEvans rats (180-220 g) of both sexes, bred at BIRDEM animal house and maintained at a constant room temperature of $22 \pm 5^{\circ} \mathrm{C}$ with humidity of $50-70 \%$ and the natural 12 hours day-night cycle. Animals were fed on a standard laboratory pellet diet and water ad labium.

Induction of diabetes in rats: Type 1 diabetes was induced by a single intraperitoneal (i.p.) injection of streptozotocin (STZ, Upjohn Company, Kalamazoo, MI USA) at a dose of $65 \mathrm{mg} / \mathrm{kg}$ body weight to adult rats (3-4 months). Confirmatory fasting blood glucose test for type 1 model rats was performed after 7 days of STZ injection. Induction of type 2 diabetes was performed using a single i.p. injection of STZ $(90 \mathrm{mg} /$ $\mathrm{kg}$ body weight) to the 48 hours old pups as described by Bonner-Weir et al. (1981). Experiments were carried out 3 months later after performing an oral glucose tolerance test.

Biological Testing: Experiments were carried out on normal, type 1 and type 2 rats according to the following scheme.

The water extracts (leaf and stem-bark) were used at a dose of $1 \mathrm{~mL} / 9 \mathrm{~mL}$ water $/ \mathrm{kg}$ body weight and $96 \%$

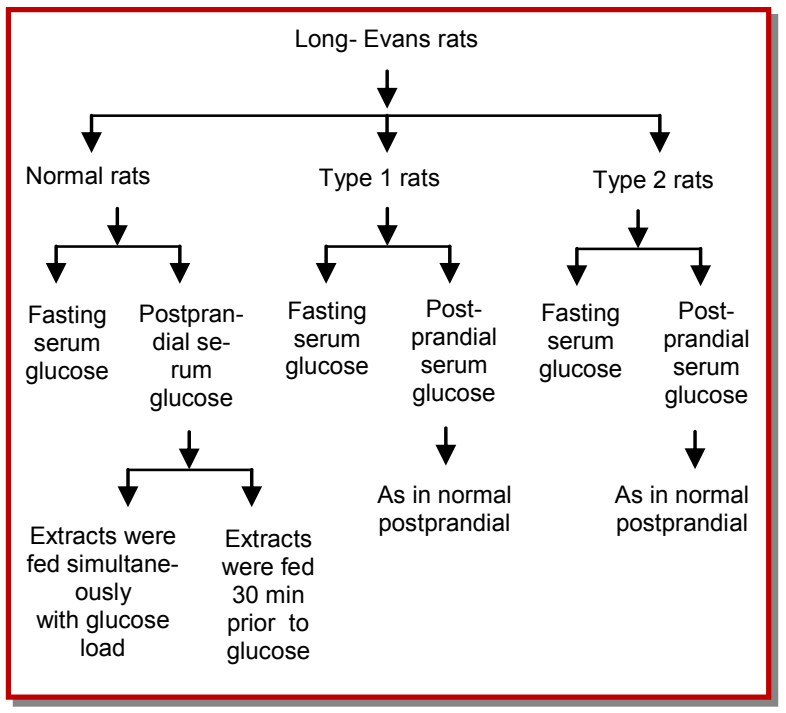

ethanol extracts (leaf and stem-bark) were used at a dose of $1.3 \mathrm{~g} / \mathrm{kg}$ body weight $/ 10 \mathrm{~mL}$. Extracts of $M$. indica were fed to the rats by smooth metallic tube under mild-ether anesthesia (Mamun et al., 2001). The control rats were given equal volume of distilled water; positive controls were given glibenclamide (5 $\mathrm{mg} / \mathrm{kg}$ ) and insulin (Actrapid HM-40 IU/mL) for type 2 and type 1 model rats respectively. Blood samples from rats were drawn by amputation of the tail tip. Blood samples were collected at 0, 60, $120 \mathrm{~min}$ for fasting conditions, at $0,30,75 \mathrm{~min}$ for simultaneous feeding of extract with glucose and at 0, 60 and 105 min when the extract was fed $30 \mathrm{~min}$ before glucose load ( $2.5 \mathrm{~g} / \mathrm{kg}$ body weight).

Effects of $M$. indica on intestinal glucose absorption: An intestinal perfusion technique (Swintosky and Pogonowska-Wala, 1982) was used to study the effects of M. indica extracts on intestinal absorption of glucose in nondiabetic and type 2 diabetic rats fasted for 36 hours and anesthetized with sodium pentobarbital $(50 \mathrm{mg} /$ $\mathrm{kg}$ ). The plant extracts were added to a kreb's solution $\left(\mathrm{g} / \mathrm{L} 1.02 \mathrm{CaCl}_{2}, 7.37 \mathrm{NaCl}, \quad 0.20 \mathrm{KCl}, \quad 0.065\right.$ $\mathrm{NaH}_{2} \mathrm{PO}_{4} .6 \mathrm{H}_{2} \mathrm{O}, 0.6 \mathrm{NaHCO}_{3}, \mathrm{pH} 7.4$ ), supplemented with glucose $(54.0 \mathrm{~g} / \mathrm{L})$ and perfused at a perfusion rate of $0.5 \mathrm{~mL} / \mathrm{min}$ for $30 \mathrm{~min}$ through the duodenum. The perfusate was collected from a catheter set at 40 $\mathrm{cm}$. M. indica extracts were added to Kreb's solution to a final conc. of $25 \mathrm{mg} / \mathrm{mL}$ so that the amount of extract in the perfused intestine is equivalent to the dose of 1.3 $\mathrm{g} / \mathrm{kg}$. The control group was perfused only with Kreb's buffer supplemented with glucose. The results were expressed as percentage of absorbed glucose, calculated from the amount of glucose in solution before and after the perfusion.

Biochemical procedures: Serum glucose levels were estimated on the same day by glucose oxidase (GODPOD) method using a commercial kit (BoehringerMannheim GmbH).

Statistical analysis: Data from the experiments were presented as mean \pm Standard deviation. Statistical analysis was done by using the Statistical Package for Social Science (SPSS) software for windows version 12 (SPSS Inc., USA). Analysis of variance (ANOVA, Bonferroni Post Test) was done to see any difference between the groups. The level of significance was set at $\mathrm{p} \leq 0.05$.

\section{Results}

Streptozotocin injection to adult rats (for simulation of type 1 diabetes) resulted in severe diabetes, which was characterized by hyperglycemia (fasting blood glucose ranging 19.8-23.2 $\mathrm{mmol} / \mathrm{L}$ ) on the $7^{\text {th }}$ day. In type 2 diabetic model rats fasting glucose level was slightly higher $(6.9-8.7 \mathrm{mmol} / \mathrm{L})$ indicating the presence of functioning $\beta$-cells. The water extracts and ethanol extracts of $M$. indica leaves and stem-barks showed no effect in nondiabetic, type 1 and 2 diabetic model rats in the fasting state (Table I). It is seen from the Table I that glibenclamide and insulin reduced serum glucose level in the fasting condition of normal and type 1 rats respectively. Glibenclamide and insulin showed significant hypoglycemic effects both at $60 \mathrm{~min}(\mathrm{p}<0.02$ and $\mathrm{p}<0.001)$ and at $120 \mathrm{~min}(\mathrm{p}<0.001)$ in normal and type1 diabetic model rats respectively.

Table II reveals that none of the extracts of $M$. indica had any significant antihyperglycemic effect in 


\begin{tabular}{|c|c|c|c|}
\hline \multicolumn{4}{|c|}{ Table I } \\
\hline \multicolumn{4}{|c|}{$\begin{array}{c}\text { Effect of } M \text {. indica of fasting blood glucose levels } \\
\text { of diabetic model rats }\end{array}$} \\
\hline Group & $\begin{array}{c}\min 0 \\
(\mathrm{mmol} / \\
\mathrm{L})\end{array}$ & $\begin{array}{c}\min 60 \\
(\mathrm{mmol} / \\
\mathrm{L})\end{array}$ & $\begin{array}{c}\min 120 \\
(\mathrm{mmol} / \\
\mathrm{L})\end{array}$ \\
\hline \multicolumn{4}{|c|}{ Nondiabetic rats } \\
\hline Water control $(n=6)$ & $6.5 \pm 0.7$ & $6.3 \pm 0.4$ & $6.5 \pm 0.7$ \\
\hline $\begin{array}{l}\text { Glibenclamide }(\mathrm{n}= \\
\text { 6) }\end{array}$ & $6.7 \pm 0.8$ & $4.7 \pm 0.6^{a}$ & $4.3 \pm 2.2^{a}$ \\
\hline M_Indica_w_l $(\mathrm{n}=8)$ & $6.3 \pm 0.8$ & $6.3 \pm 1.0$ & $6.2 \pm 1.1$ \\
\hline $\begin{array}{l}\text { M_Indica_eth_l }(\mathrm{n}= \\
\text { 7) }\end{array}$ & $6.8 \pm 0.8$ & $7.0 \pm 0.8$ & $6.8 \pm 0.7$ \\
\hline M_Indica_w_b (n = & $6.9 \pm 0.4$ & $6.9 \pm 0.9$ & $7.0 \pm 0.9$ \\
\hline $\begin{array}{l}\text { M_Indica_eth_b }(\mathrm{n}= \\
8)\end{array}$ & $7.0 \pm 0.5$ & $6.6 \pm 0.8$ & $7.0 \pm 1.0$ \\
\hline \multicolumn{4}{|c|}{ Type 1 diabetic model rats } \\
\hline Water control $(n=6)$ & $20.6 \pm 3.0$ & $21.2 \pm 2.4$ & $19.4 \pm 3.9$ \\
\hline Insulin $(n=6)$ & $22.2 \pm 2.2$ & $5.4 \pm 4.5^{\mathrm{a}}$ & $4.5 \pm 3.9 \mathrm{a}$ \\
\hline M_Indica_w_l $(\mathrm{n}=7)$ & $19.8 \pm 4.1$ & $19.4 \pm 4.1$ & $18.6 \pm 4.2$ \\
\hline $\begin{array}{l}\text { M_Indica_eth_l }(n= \\
6)\end{array}$ & $21.1 \pm 3.7$ & $20.7 \pm 2.6$ & $19.8 \pm 2.2$ \\
\hline M) & $20.0 \pm 3.8$ & $21.8 \pm 3.6$ & $20.1 \pm 3.5$ \\
\hline $\begin{array}{l}\text { M_Indica_eth_b }(n= \\
\text { 9) }\end{array}$ & $23.2 \pm 5.3$ & $21.0 \pm 4.3$ & $18.9 \pm 3.7$ \\
\hline \multicolumn{4}{|c|}{ Type 2 diabetic model rats } \\
\hline Water control $(n=6)$ & $8.7 \pm 1.5$ & $9.1 \pm 2.6$ & $9.0 \pm 3.0$ \\
\hline $\begin{array}{l}\text { Glibenclamide }(n= \\
\text { 6) }\end{array}$ & $8.1 \pm 1.3$ & $7.3 \pm 0.7$ & $6.6 \pm 0.9$ \\
\hline M_Indica_w_l $(\mathrm{n}=7)$ & $8.4 \pm 1.6$ & $8.6 \pm 2.0$ & $7.6 \pm 1.6$ \\
\hline $\begin{array}{l}\text { M_Indica_eth_l }(\mathrm{n}= \\
\text { 7) }\end{array}$ & $7.6 \pm 1.5$ & $8.8 \pm 3.1$ & $9.1 \pm 3.6$ \\
\hline $\begin{array}{l}\text { M_Indica_w_b }(n= \\
\text { 7) }\end{array}$ & $6.9 \pm 1.2$ & $6.4 \pm 0.6$ & $6.3 \pm 0.5$ \\
\hline M_Indica_eth_b $(\mathrm{n}=$ & $8.0 \pm 1.8$ & $9.3 \pm 3.4$ & $9.2 \pm 2.9$ \\
\hline $\begin{array}{l}\text { ANOVA (Bonferroni test } \\
{ }^{a} \mathrm{p}<0.01 ; \mathrm{n}=\text { number of rat }\end{array}$ & was done & the test o & gnificance. \\
\hline
\end{tabular}

nondiabetic and type 1 model rats when fed simultaneously with glucose load. On the contrary, all of the extracts of $M$. indica showed significant antihyperglycemic effect at $30 \mathrm{~min}(\mathrm{p}<0.002-0.001)$ as well as at 75 min $(p<0.05-0.001)$ when fed simultaneously with oral glucose load in type 2 model rats (Table II). Glibenclamide showed a significant fall in serum glucose level at $75 \mathrm{~min}(\mathrm{p}<0.001)$ in normal rats. In type 1 diabetic model rats, insulin showed significant antihyperglycemic effect at both time points at $30 \mathrm{~min}$ and at $75 \mathrm{~min}(\mathrm{p}<0.001)$.

As it is seen from Table III that none of the extracts of $M$. indica showed any significant hypoglycemic effect in nondiabetic and type 1 model rats in postprandial condition when the extracts were fed $30 \mathrm{~min}$ prior to glucose load. In type 2 model rats, it was evident that water and ethanol extract of leaves had no significant effect but ethanol extract of stem barks of $M$. indica had significant antihyperglycemic effect at $105 \mathrm{~min}$

\begin{tabular}{|c|c|c|c|}
\hline \multicolumn{4}{|c|}{ Table II } \\
\hline \multicolumn{4}{|c|}{$\begin{array}{l}\text { Effect of } M \text {. indica on blood glucose levels diabet- } \\
\text { ic model rats when the extracts were fed simulta- } \\
\text { neous with glucose load }\end{array}$} \\
\hline Group & $\begin{array}{c}\min 0 \\
(\mathrm{mmol} / \\
\mathrm{L})\end{array}$ & $\begin{array}{c}\min 30 \\
(\mathrm{mmol} / \\
\mathrm{L})\end{array}$ & $\begin{array}{c}\min 75 \\
(\mathrm{mmol} / \mathrm{L})\end{array}$ \\
\hline \multicolumn{4}{|c|}{ Nondiabetic rats } \\
\hline $\begin{array}{l}\text { Water control }(n= \\
6)\end{array}$ & $6.4 \pm 0.9$ & $7.8 \pm 1.1$ & $7.4 \pm 0.9$ \\
\hline $\begin{array}{l}\text { Glibenclamide (n } \\
=6 \text { ) }\end{array}$ & $6.4 \pm 1.01$ & $7.7 \pm 0.8$ & $5.2 \pm 0.7 \mathrm{~b}$ \\
\hline $\begin{array}{l}\text { M_Indica_w_l }(n= \\
7)\end{array}$ & $6.1 \pm 1.0$ & $7.4 \pm 0.6$ & $6.8 \pm 0.8$ \\
\hline $\begin{array}{l}\text { M_Indica_eth_l(n } \\
=7)\end{array}$ & $6.2 \pm 1.1$ & $8.3 \pm 1.4$ & $7.6 \pm 0.7$ \\
\hline $\begin{array}{l}\text { M_Indica_w_b (n } \\
=7)\end{array}$ & $6.5 \pm 1.0$ & $8.4 \pm 0.3$ & $7.7 \pm 0.7$ \\
\hline $\begin{array}{l}\text { M_Indica_eth_b (n } \\
=7)\end{array}$ & $6.2 \pm 1.0$ & $8.0 \pm 0.8$ & $7.5 \pm 0.4$ \\
\hline \multicolumn{4}{|c|}{ Type 1 diabetic model rats } \\
\hline $\begin{array}{l}\text { Water control }(\mathrm{n}= \\
6)\end{array}$ & $24.9 \pm 2.3$ & $30.9 \pm 3.3$ & $29.2 \pm 3.3$ \\
\hline Insulin $(n=6)$ & $23.8 \pm 3.3$ & $18.6 \pm 4.2^{\mathrm{b}}$ & $8.8 \pm 3.5^{b}$ \\
\hline $\begin{array}{l}\text { M_Indica_w_l }(n= \\
6)\end{array}$ & $22.8 \pm 3.5$ & $28.7 \pm 4.4$ & $27.2 \pm 2.7$ \\
\hline $\begin{array}{l}\text { M_Indica_eth_l (n } \\
=6)\end{array}$ & $23.8 \pm 3.6$ & $28.3 \pm 3.5$ & $26.7 \pm 2.9$ \\
\hline $\begin{array}{l}\text { M_Indica_w_b (n } \\
=6)\end{array}$ & $23.8 \pm 1.9$ & $28.9 \pm 1.8$ & $25.4 \pm 3.8$ \\
\hline $\begin{array}{l}\text { M_Indica_eth_b (n } \\
=6)\end{array}$ & $22.5 \pm 2.6$ & $29.1 \pm 3.8$ & $26.6 \pm 1.6$ \\
\hline \multicolumn{4}{|c|}{ Type 2 diabetic model rats } \\
\hline $\begin{array}{l}\text { Water control }(n= \\
6)\end{array}$ & $8.6 \pm 0.9$ & $15.4 \pm 2.1$ & $15.6 \pm 1.8$ \\
\hline $\begin{array}{l}\text { Glibenclamide (n } \\
=6 \text { ) }\end{array}$ & $7.5 \pm 1.4$ & $13.8 \pm 2.5$ & $11.7 \pm 2.0$ \\
\hline $\begin{array}{l}\text { M_Indica_w_l }(n= \\
6)\end{array}$ & $6.7 \pm 1.2$ & $9.6 \pm 2.6^{b}$ & $9.8 \pm 2.7 b$ \\
\hline $\begin{array}{l}\text { M_Indica_eth_1 (n } \\
=6)\end{array}$ & $7.8 \pm 1.6$ & $10.7 \pm 1.6^{b}$ & $10.9 \pm 2.5^{a}$ \\
\hline $\begin{array}{l}\text { M_Indica_w_b (n } \\
=6)\end{array}$ & $8.3 \pm 1.7$ & $10.6 \pm 1.6^{b}$ & $10.5 \pm 1.2^{b}$ \\
\hline $\begin{array}{l}\text { M_Indica_eth_b(n } \\
=6)\end{array}$ & $8.0 \pm 1$ & $10.3 \pm 1.5^{a}$ & $11.6 \pm 2.5^{\mathrm{a}}$ \\
\hline $\begin{array}{l}\text { ANOVA (Bonferroni } \\
{ }^{\mathrm{a}} \mathrm{p}<0.05-0.01,{ }^{\mathrm{b}} \mathrm{p}<0.001 \text {; }\end{array}$ & $\begin{array}{l}\text { st) was dor } \\
=\text { number } \mathrm{o}\end{array}$ & as the test & significance. \\
\hline
\end{tabular}

$(p<0.01)$ when fed prior to oral glucose load (Table III). Glibenclamide showed significant antihyperglycemic effect in normal rats at both time points that is at 60 $\min (\mathrm{p}<0.001)$ and $105 \mathrm{~min}(\mathrm{p}<0.01)$; at $105 \mathrm{~min}$ $(\mathrm{p}<0.01)$ for type 2 model rats respectively. On the other hand, insulin in type 1 diabetic model significantly lowered serum glucose levels at both time points i.e. at $60 \mathrm{~min}$ and at $105 \mathrm{~min}(\mathrm{p}<0.01)$.

Figures 1 and 2 show the effect of ethanol extracts of stem barks and leaves of $M$. indica on upper intestinal glucose absorption in normal and type 2 diabetic rats respectively. The percent of glucose absorbed across the intestine was higher during the whole period of perfusion in normal and type 2 rats. The supplemen- 


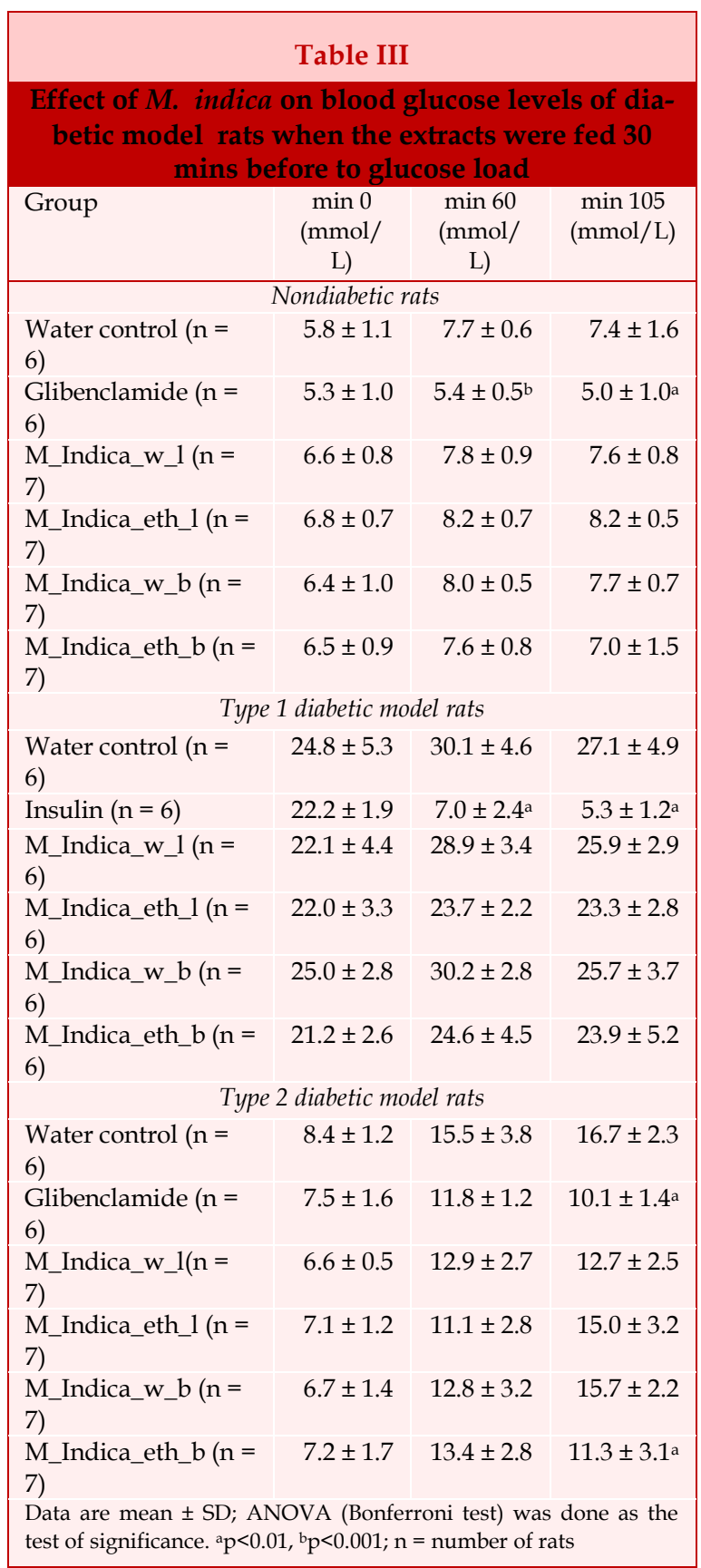

tation of the perfusion medium either with ethanol extracts of barks or leaves of M. indica in normal rats did not affect the amount of absorbed glucose throughout the whole period of experiment in normal rats (Figure 1). However, in type 2 diabetic models, supplementation of the medium with ethanol extracts of stem-barks reduced glucose absorption during the whole perfusion period (13-15\% reduction after $25-30$ min) (Figure 2).

\section{Discussion}

Our results demonstrate that all the extracts of $M$.

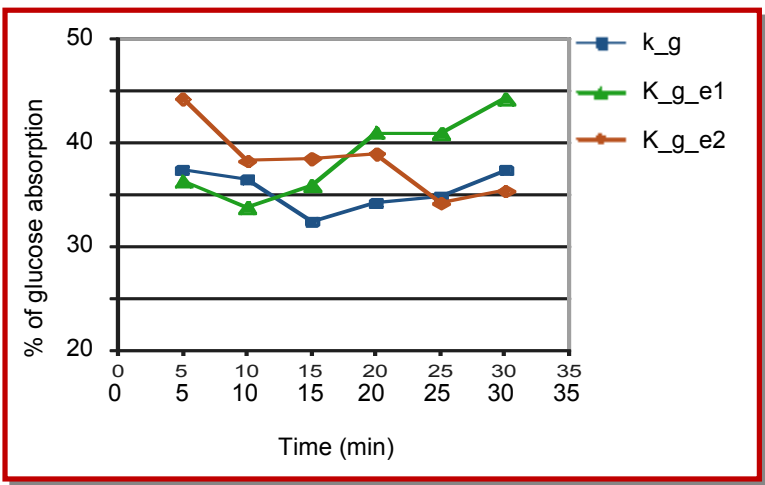

Figure 1: Effect of the M. indica on upper intestinal glucose absorption on normal rats

Results are presented as mean \pm SD $(n=6)$. Rats were fasted for 36 hours and intestine was perfused with glucose solution $(54 \mathrm{~g} / \mathrm{L})$ with or without ethanol extracts of $M$. indica $(25 \mathrm{mg} / \mathrm{mL}) . \mathrm{k} \_\mathrm{g}=$ Krebs buffer supplemented with glucose; K_g_e1 = Ethanol extract of leaves; K_g_e2 = Ethanol extract of stem barks

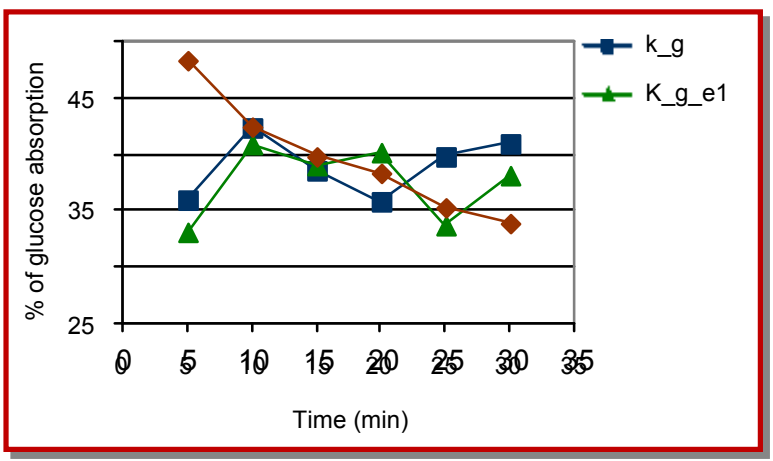

Figure 2: Effect of the M. indica on upper intestinal glucose absorption on type 2 diabetic rats

Results are presented as mean \pm SD $(n=6)$. Rats were fasted for 36 hours and intestine was perfused with glucose solution $(54 \mathrm{~g} / \mathrm{L})$ with or without ethanol extracts of $M$. indica $(25 \mathrm{mg} / \mathrm{mL})$. k_g = Krebs buffer supplemented with glucose; $\quad$ K_g_e1 $=$ Ethanol extract of leaves; K_g_e2 = Ethanol extract of stem

indica leaves and stem barks showed significant antihyperglycemic effect in type 2 diabetic model rats when the extracts were fed simultaneously with glucose. Single oral administration of a dose of 250 $\mathrm{mg} / \mathrm{kg}$ body weight produces a potent and strong hypoglycemic effect in type 2 rats. The obtained results are supported by the finding of other investigators (Sharma et al., 1997; Aderibigbe et al., 2001).

Hypoglycemic activity that is found when given with a simultaneous glucose load in diabetic rats indicates that the extracts may interfere with the intestinal glucose absorption in the gut by various mechanisms (Nahar et al., 2000; Vinik and Wing, 1990; Lempcke, 1987). It may be postulated that the extracts of $M$. indica might stimulate glycogenesis in the liver, which is enhanced by feeding (Creutzfeld et al., 1979). This effect was confirmed by Perpetus et al. where they showed that blood glucose level of diabetic rats consuming mango flour for 90 days decreased $66 \%$ in comparison to control rats. It was also observed that hepatic glycogen level of those diabetic rats was $64 \%$ greater then control. The author claimed that this increase in glycogen level might have contributed to 
the reduction of blood glucose level in these animals.

Ethanol extract of stem bark of $M$. indica was also effective in type 2 diabetic model rats when fed $30 \mathrm{~min}$ might be due to a systemic action, i.e. as a result of the stimulation of pancreatic $\beta$-cells and improving the insulin secretory capacity or enhancement of insulin action by the extract. This effect could not be confirmed by our study since serum insulin level after a single feeding was not determined. It has been claimed that the chronic intraperitoneal administration of mangiferin (a xanthone glucoside, isolated from the leaves of $M$. indica) at a dose of 10 and $20 \mathrm{mg} / \mathrm{kg}$ once daily for 28 days exhibited antidiabetic activity by lowering fasting plasma glucose level significantly at different time intervals in STZ diabetic rats and improved glucose tolerance. The accumulating eviden-ces suggest that both pancreatic and extra pancreatic mechanisms might be involved in its antidiabetic or antihyperglycemic action (Muruganandan et al., 2005).

One of the objectives of the present study was to investigate whether the hypoglycemic effect is related to the inhibition of glucose absorption in the gut. This was investigated in gut perfusion experiment where the ethanol extracts of stem barks showed gradual decrease in glucose absorption. Aderibigbe et al. claimed that hypoglycemic effect of the aqueous extract of leaves of $M$. indica was compatible with chlorpropamide (an oral hypoglycemic agents) and the action may be parts due to an intestinal reduction of the absorption of glucose. Therefore, the activity of the extracts of M. indica does not seem to be mediated by increasing insulin secretion or insulin sensitivity since it is not active in type 1 model rats.

Thus it may be concluded from the present study that the antidiabetic activity of M. indica is probably at least, partly due to inhibition of glucose absorption in the gut.

\section{Acknowledgements}

We gratefully acknowledge the financial and logistic supports provided by the International Program in the Chemical Sciences (IPICS), Uppsala University Sweden and Diabetic Association of Bangladesh.

\section{References}

Aderibigbe AO, Emudianughe TS, Lawal BAS. Evaluation of the antidiabetic action of Mangifera indica in mice. Phytotherapy Res. 2001; 15: 456-58.
Ali L, Khan AKA, Mamun MIR, Mosihuzzaman M, Nahar N, Nur-E-Alam M, Rokeya B. Studies on hypoglycemic effects of fruit pulp, seed and whole plants of Momordica charantia on normal and diabetic model rats. Planta Medica. 1993; 59: 408-12.

Bonner-Weir S, Trent DF, Honey RN, Weir GC. Responses of neonatal rat islets on streptozotocin-limited beta cell regeneration and hyperglycemia. Diabetes 1981; 30: 64-69.

Creutzfeld W. The incretin concept today. Diabetologia 1979; 16: 75-85.

Lempcke B. Control of absorption: Delaying absorption as a therapeutic principle. In: Structure and function of the $\mathrm{Z}$ small Intestine. Cospary WF (ed). New York, Elsevier, 1987, pp 263-80.

Mahabir D, Gulliford MC. Use of medicinal plants for diabetes in Trinidad and Tobago. Rev Panam Salud Publica. 1997; 3: 174-79.

Mamun MIR, Rokeya B, Choudhury NS, Muniruzzaman M, Nahar N, Ahmed MU, Mosihuzzaman M, Ali L, Khan AKA, Khan SH. Anti-hyperglycemic effect of Pterospermum acerifolium Wild and Pterospermum semisagittatum Ham Diabetes Res. 2001; 35: 163-70.

Muruganandan K, Srinivasan S, Gupta PK, Gupta JL. Effect of mangiferin on hyperglycemia and atherogenicityin streptozotocin diabetic rats. J Ethnopharmacol. 2005; 93: 497-501.

Nahar N, Rokeya B, Ali L, Hassan Z, Nur-e-Alam M, Choudhury NS, Khan AKA, Mosihuzzaman M. Effect of three medicinal plants on blood glucose levels in nondiabetic and diabetic model rats. Diabetes Res. 2000; 35: 41-49.

Ojewole J. Anti-inflammatory, analgesic and hypoglycemic effects of Mangifera indica Linn. (Anacardiaceae) stem-bark aqueous extract. Methods Find Exp Clin Pharmacol. 2005; 27: 547-54.

Perpetuo JM, Salgado JM. Effect of mango (Mangifera indica Linn) ingestion on blood glucose levels of normal and diabetic rats. Plant Foods Human Nutr. 2003; 58: 1-12.

Swintosky J, Pogonowska-Wala E. The in situ rat gut technique: A simple, rapid, inexpensive way to study factors influencing drug absorption rate from the intestine. Pharmacy Int. 1982; 3: 163-64.

Sharma SR, Dwivedi SK, Swarup D. Hypoglycemic potential of Mangifera indica leaves in rats. Pharmaceutical Biol. 1997; 35: 130-33.

Trivedi NA, Majumder B, Bhatt JD, Hemavathi KG. Effect of Shilajit on blood glucose and lipid profile in alloxaninduced diabetic rats. Indian J Pharmacol. 2004; 36: 373-76.

Vinik A, Wing RR. In: Diabetes mellitus: Theory and practice. Rifkin H, Porte D Jr. (eds). 2nd ed. New York, Elsevier, 1990, pp 465-97. 